\title{
Anxiety of Not Being Appointed: A Qualitative Study
}

\author{
Mehmet Özcan, Mustafa Kemal Yöntem \& Ahmet Galip Yücel \\ Nevşehir Hacı Bektaş Veli University, Faculty of Education, TURKEY
}

Received: 26 March 2021 • Accepted: 4 June 2021 • Published Online: 10 July 2021

\begin{abstract}
This study aims to reveal the opinions of the senior students of education faculty about the anxiety of not being appointed. Phenomenological research design is used in this research. The convenience sampling method was used in the selection of the participants. The data of the study is collected through face-to-face individual interviews with the students. The research form consists of 2 parts. The questions in the first part are about the demographic information of the participants. The second part includes questions aiming to reveal the experiences of the participants regarding the anxiety of not being appointed. Each interview lasted 20 minutes on average. All interviews conducted within the scope of the research were recorded using a voice recorder with the permission of the participants. Descriptive analysis was used in the analysis of data. According to the findings, it was observed that family expectations affected all of the participants who had anxiety about not being appointed. All of the prospective teachers who experienced anxiety about not being appointed were found to catastrophize the situation. Five of the participants who had anxiety about not being appointed had physiological symptoms and that anxiety affected daily life. Three of the participants who experienced anxiety about preparation for appointment stated that they had no additional effort to be appointed. All of the participants stated that they used social support mechanisms for anxiety.
\end{abstract}

Keywords: senior student, unappointment, anxiety, unappointed anxiety.

\section{Introduction}

Anxiety is a state of mind that is present in the personality traits of individuals or experienced by an individual in the face of an occurrence. When individuals with anxiety have a high perceived threat, their self-efficacy to cope with these threats is low (Johnson \& Melamed, 1979). Several causes, such as feeling helpless, receiving threats, stress, or expectations may lead to the emergence of anxiety (Mckenzie, 2006). Basic reasons that lead to anxiety in individuals can be listed as uneasiness, restlessness, despair, and uncertainty. When defined generally, anxiety is a mood in which the thought that something bad is going to happen causes concerns and discomfort in the individual (Anthony \& Swinson, 2000). An individual with anxiety is in an uncomfortable and threatening mood due to external factors (Smith \& Lazarus, 1990). When definitions of anxiety are examined, it can be said that it is a mood that causes a change in the physiological state and behavior of the individual and is perceived as threatening. However, anxiety is a mood acquired in the evolutionary process. Thanks to this feeling, human beings exhibit pain avoidance behavior and protect themselves from dangerous situations. When faced with a real threat, anxiety helps individuals to be alert to ensure their safety. When the level of anxiety increases, this may affect performance. In other words, the state of anxiety can positively

(C) Authors. Terms and conditions of Creative Commons Attribution 4.0 International (CC BY 4.0) apply. Correspondence: Mehmet Özcan, Qiqihar Nevşehir Hacı Bektaş Veli University, Faculty of Education, Nevşehir, TURKEY. E-mail: mehmetozcan79@gmail.com. 
affect the motivation, life, working life, and social life of the individual at a certain level; however, this effect becomes negative as the level of anxiety increases. The Yerkes-Dodson Law (1908) explains this phenomenon well. According to the model, while performance decreases in situations where the level of anxiety is low or high, it reaches a maximum level when the level of anxiety is moderate.

As can be seen, anxiety can be studied under two headings as positive and negative. Accordingly, negative anxiety causes an individual to feel upset and to be negatively affected by a situation they encounter, while positive anxiety causes the motivation and success of the individual to increase (Scovel, 1978). The positive mood that anxiety creates in the individual enables the individual to feel good and to think sensibly (Manav, 2010). The capacity to control anxiety can lead individuals to success (Semerci, 2007).

Anxiety is generally expressed in two ways, namely, state and trait anxiety. State anxiety can be defined as the state of uneasiness and anxiety felt by an individual in a certain situation. It is a complex and fear-focused emotion that emerges in the continuation of a situation that the individual evaluates as stressful (Spielberger, 1972). It involves physiological changes, such as sweating, tension, and blushing, that an individual experiences as a result of worrying about a situation (Öner \& Le Compte, 1998). Trait anxiety, on the other hand, can be defined as the state of mind that is perceived externally and does not involve a threat and that the individual experiences internally. Also, an important explanation about anxiety has been made within the scope of cognitive-behavioral therapies. According to cognitive-behavioral therapies, cognitive distortions (Beck, John Rush, Shaw \& Emery, 1979; Fair, 1986: Burns, 2014) underlie the negative anxiety experienced by individuals.

When the concept of anxiety is considered from a developmental perspective, it can be seen that developmental periods create different sources of anxiety. Individuals go through different developmental stages throughout their lives and have to fulfill certain developmental tasks at each stage. Particularly in young adulthood, career planning and the goal of gaining economic independence, as well as establishing close relationships, becomes more important. Individuals may experience anxiety about fulfilling these tasks in young adulthood. According to some studies, university students are anxious about the future. This anxiety experienced by students is mainly related to finding a job, career, place of residence, and economic expectations. The feeling of hopelessness, anxiety, and uncertainties experienced in the decision-making process in individuals makes up future anxiety (Çokluk, 2000). Realizing uncertainties and seeing that there is a future that they cannot control causes future anxiety in individuals (Tarhan, 2012). In this context, university students are expected to experience future anxiety. Future anxiety can be generally expressed as the uncertainty about the future of the individual. The level of anxiety rises when the individual cannot find an answer to these uncertainties. Future anxiety consists of negative experiences and environmental reasons in the individual (Zaleski, 1996).

One of the most important sources of future anxiety faced by young adults in Turkey is finding the right job and starting to work. While the recruitment conditions of every country differ, anxiety levels also differ. In Turkey, prospective teachers earn an undergraduate degree. The number of teachers working in formal educational institutions in Turkey in the 20192020 academic year was 1,077,307. Of these teachers, 907,567 worked in public schools and 169,740 in private schools. As can be seen, $75 \%$ of teachers in Turkey are employed by state schools. Also, issues such as personal rights, job security, and the salary of teachers in private schools are generally problematic. To work in public schools, prospective teachers take the common test called the public personnel selection test and those who get enough scores start working as teachers. According to the data of the Ministry of National Education (MEB), 376,709 unemployed teachers (around 460,000 according to the data of a teachers' association), are waiting for an appointment, in addition to those who have received teacher training. While some unemployed people with a degree try to hold on to life by working in various jobs, others give up 
their dream of teaching because they have not been appointed. In addition, the number of teachers who will not have been appointed by 2023 is expected to reach 1 million.

The disappointment of individuals who have graduated from teacher training programs in Turkey but cannot be appointed as teachers in the public sector has been addressed in the Strategy Document prepared by the Ministry of National Education (MEB, 2017: 6). This issue is also known by the state. Given that the number of teachers who were not appointed despite applying for the common test as of 2016 in the same document is 438,134 (Ibid.: 6), the importance of the problem becomes more obvious. Almost half a million teachers applied for the common test in 2016, and nearly 17,000 teachers were employed. This data shows that only 3-4\% of the individuals who apply for the test are appointed every year. Mutlu et al. (2019) revealed that approximately $80 \%$ of prospective teachers wanted to be employed in public schools primarily. When this data is evaluated together with the number of people employed, it can be said that at least 350,000 teachers each year have the potential to experience anxiety about not being appointed. This shows that we confront a problem that requires action. In the last two years, the story of 42 prospective teachers who have failed to be appointed to public school and ended their lives has appeared in the media and been the subject of a parliamentary motion (Yeni Çă̆, 2018). According to the general opinion of the public, these prospective teachers who committed suicide made this decision because they were not appointed to public schools. This major social problem is significant in terms of showing the importance prospective teachers attach to being appointed to public schools. For this reason, the anxiety of not being appointed must be an undeniable issue in scientific studies.

Due to all of these causes, it is thought that prospective teachers in Turkey experience anxiety about not being appointed. Accordingly, this study aimed to examine the foundations of the anxiety about not being appointed, which is a new concept in the literature. The basic components underlying the anxiety of not being appointed were examined and solution suggestions were put forward.

\section{Method}

The method of this study is presented in the following sections, titled objective of the study, study group, data collection tools, data collection, data analysis, and validity and reliability.

\subsection{Objective of the study}

This study aimed to reveal the opinions of the senior students of education faculty about the anxiety of not being appointed. In this context, the study used a phenomenological research design, which is one of the qualitative research approaches. Qualitative research is the process of developing a field-specific explanation and theory by investigating the meanings individuals attribute to concepts (Özden \& Saban, 2017). Phenomenological research aims to explain people's tangible experiences about a concept or phenomenon (Johnson \& Christensen, 2014). This method was chosen to reveal the experiences of the senior students in the education faculty during their appointment to teacher position.

\subsection{Research group}

The convenience sampling method was used in the selection of the participants. For this purpose, senior students from the education faculty of a university in the Central Anatolia region were informed about the research, and the students who volunteered to participate in the study were recruited. Table 1 presents information about the participants. 
Table 1. Information about the participants

\begin{tabular}{|c|c|c|c|c|c|}
\hline $\begin{array}{l}\text { Particip } \\
\text { ants }\end{array}$ & $\underset{t}{\text { Departmen }}$ & $\begin{array}{l}\text { Perceived } \\
\text { economic } \\
\text { status }\end{array}$ & $\begin{array}{c}\text { Number of } \\
\text { siblings / birth } \\
\text { order }\end{array}$ & $\begin{array}{l}\text { Level of } \\
\text { father's } \\
\text { education }\end{array}$ & $\begin{array}{c}\text { Level of } \\
\text { mother's } \\
\text { education }\end{array}$ \\
\hline N1 & ELT & Middle & $4 / 3^{\text {rd }}$ & $\begin{array}{l}\text { Elementary } \\
\text { School }\end{array}$ & $\begin{array}{l}\text { Elementary } \\
\text { School }\end{array}$ \\
\hline $\mathrm{N} 2$ & ELT & Middle & $2 / 1^{\mathrm{st}}$ & Middle School & $\begin{array}{l}\text { Elementary } \\
\text { School }\end{array}$ \\
\hline N3 & ELT & Good & $2 / 1^{\text {st }}$ & High School & High School \\
\hline $\mathrm{N} 4$ & ELT & Middle & $9 / 5^{\text {th }}$ & Middle School & $\begin{array}{l}\text { Elementary } \\
\text { School }\end{array}$ \\
\hline N5 & $\begin{array}{l}\text { Primary } \\
\text { Math } \\
\text { Teaching }\end{array}$ & Middle & $3 / 1^{\mathrm{st}}$ & Undergraduate & High School \\
\hline N6 & $\begin{array}{l}\text { Primary } \\
\text { Math } \\
\text { Teaching }\end{array}$ & Good & $4 / 4^{\text {th }}$ & Undergraduate & High School \\
\hline N7 & $\begin{array}{l}\text { Primary } \\
\text { Math } \\
\text { Teaching }\end{array}$ & Good & $3 / 1^{\mathrm{st}}$ & Undergraduate & High School \\
\hline N8 & $\begin{array}{l}\text { Turkish } \\
\text { Language } \\
\text { Teaching. }\end{array}$ & Middle & $3 / 1^{\mathrm{st}}$ & Undergraduate & High School \\
\hline N9 & $\begin{array}{l}\text { Turkish } \\
\text { Language } \\
\text { Teaching. }\end{array}$ & Middle & $6 / 5^{\text {th }}$ & Middle School & $\begin{array}{l}\text { Elementary } \\
\text { School }\end{array}$ \\
\hline N10 & $\begin{array}{l}\text { Social } \\
\text { Studies } \\
\text { Teaching }\end{array}$ & Middle & $3 / 1^{\mathrm{st}}$ & High School & Middle School \\
\hline N11 & $\begin{array}{l}\text { Social } \\
\text { Studies } \\
\text { Teaching }\end{array}$ & Middle & $3 / 3^{\text {rd }}$ & Middle School & $\begin{array}{l}\text { Elementary } \\
\text { School }\end{array}$ \\
\hline N12 & $\begin{array}{l}\text { Social } \\
\text { Studies } \\
\text { Teaching }\end{array}$ & Poor & $5 / 2^{\text {nd }}$ & $\begin{array}{l}\text { Elementary } \\
\text { School }\end{array}$ & $\begin{array}{l}\text { Elementary } \\
\text { School }\end{array}$ \\
\hline
\end{tabular}

\subsection{Data collection tool and data collection}

The data of the study were collected through face-to-face individual interviews with the students. The research form consists of 2 parts. The questions in the first part are about the demographic information of the participants. The second part includes questions aiming to reveal the experiences of the participants regarding the anxiety of not being appointed. Each interview lasted 20 minutes on average. The answers to the research questions were audio-recorded with the permission of the participants, were transcribed in 2 weeks, and transferred to a computer file. In the study, participants were asked 6 questions to reveal their experiences regarding the anxiety of not being appointed. The questions are as shown in Table 2.

Table 2. Research questions

1. Are you worried that you may not be appointed?

2. What does 'the likelihood of not being appointed" mean to you?

3. What are the factors that cause you anxiety?

4. Does the anxiety you experience have any effect on your physiological state? 
5. What do you think will happen when you are not appointed?

6. Are you doing any preparation to get appointed?

\subsection{Trustworthiness}

In the study, the methods of obtaining expert opinion (Ylddırım \& Şimşek, 2000), participant confirmation (Merriam, 2013), and rich description (Creswell, 2016) were used together for trustworthiness. First of all, the items and themes in the research forms were submitted to the opinions of three experts with a $\mathrm{PhD}$ in guidance and counseling and an expert with a PhD in clinical psychology. During the interviews, special attention was paid to ensure that the participants were not influenced by the researcher while they were answering the questions. In addition, participant confirmation method was employed after coding the research data. This method allows participants to check whether the study findings reflect their own thoughts correctly (Merriam, 2013), and it is defined as the most functional technique in terms of validity (Creswell, 2016). Within the scope of this study, the findings obtained while applying participant confirmation were discussed with the participants. In addition, while presenting the findings of the study, the rich description method was applied by including participant views (Ibid.).

\subsection{Data analysis}

All interviews conducted within the scope of the research were recorded using a voice recorder with the permission of the participants. The interviews recorded were later converted to text. The texts were analyzed line by line. Descriptive analysis was used in the analysis of data. The data obtained were summarized and analyzed in accordance with the coding process results. In addition, some direct quotations were included to strengthen the report.

\section{Results}

In this section, firstly, the model related to research findings is shown in figure 1. After that, the themes were given together with the statements of participants.

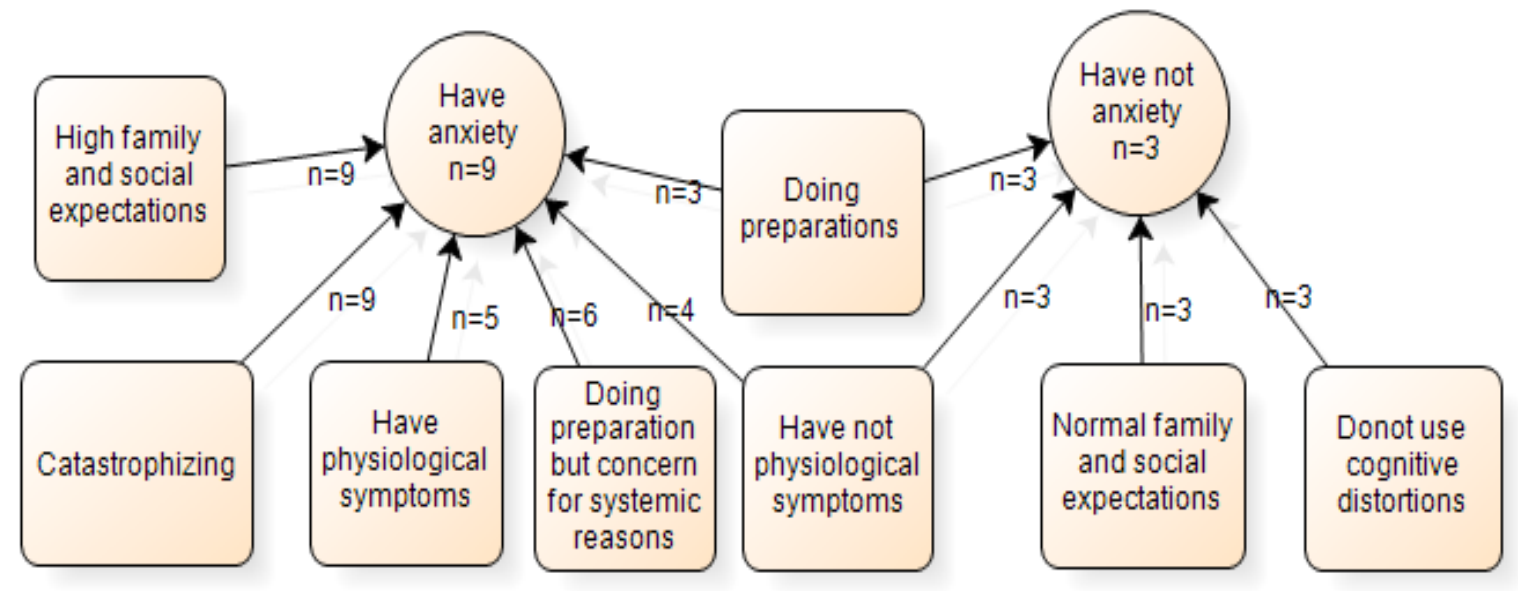

Figure 1. The model for the findings 


\subsection{Anxiety about not being appointed}

The majority of the participants stated that they experienced anxiety about not being appointed $(n=9)$. The statements of some participants who stated that they experienced anxiety about not being appointed are as follows.

N8: Not being appointed is very upsetting, and it is also a bit disappointing because too much is expected of me. I am expected to be very successful.

N12: Yes. We are starting to go through hard times. It's distressing. Anxiety starts in the fourth year. What if not appointed? What will happen? Will the four years be wasted? How will I look at their faces when I go to my village?

The opinions of some participants who did not experience anxiety are as follows.

N5: I'm not very concerned because if I cannot be appointed, this is not the end of everything. I think that I should not strain myself mentally for this reason... You know, there are options, or there are many ways that one can follow in relation to his/her profession. We are making plans accordingly. For example, I want to do a master's degree.

N3: I think what matters is one's own character, thoughts, and point of view. I'm not very concerned because this is not the end of everything if I cannot be appointed. I don't think I need to mentally strain myself for this reason, either... I don't experience much anxiety.

\subsection{The effect of family and social environment expectations on anxiety}

According to the findings, it was observed that family expectations affected all of the participants who had anxiety about not being appointed. Some of the participants' expressions are as follows.

N8: They expect that I can do my best. That's why I am trying to do my best, but of course we experience anxiety because they say "you can do it".

N4: Yes, because they have been expecting a lot from me since I was very young. Even now they consider me as appointed. Upsetting them will impact me deeply.

N12: Generally. Not just family. After all, if you come from a small place, you are something higher in their eyes because of the small number of people who are students there. You seem to be a more cultured, educated, well-equipped person with a certain profession. When they are disappointed, your degree in their eyes falls. If we look at the anxiety in terms of my family, they know that I am not here just to study. They say, "We know you're doing your best," because they know the fight I'm giving against life. They say I can try again once more if I fail. I do not think my life will come to a halt or everything will be over. I am doing my best. I am studying enough. If I had worked in a job with social security for four years, I could feel more secure now. I do not even have that. I am following the life four years behind. After graduation, you cannot ask for money from your family. You should make some contributions to them, instead. They are also getting old and wearing down. You have to help them. Your responsibility increases even more. I consider them all. I have been experiencing anxiety internally, but I am not showing it.

N2: Actually, I am scared of the next year's uncertainty more. In fact, I do not think I will be appointed this year. I have even given up hope. Especially, my mom says I will be appointed. Sometimes when I get a low score, they say, "No. We do not believe you can get a low score". They have high expectations from me. 
N11: I think that, particularly, my family and environment have contributed to my anxiety. This is not a direct pressure of the family, but an indirect pressure because I know what they want and their high expectations.

N10: I have grown up with this anxiety since my childhood. When I got a 100 from a test, my family would ask why I did not get 200." They made me feel like this, albeit jokingly. It continued in this way until high school.

It was observed that the participants who did not have anxiety of not being appointed did not have any problems regarding family and social environment expectations. The views of two of the participants are as follows.

N5: My mother said, "Do not worry about KPSS (the common test) too much. If you cannot be appointed, you can give private lessons or work in a private school. It is not that important." Nobody is putting pressure on me.

N3: My family does not tell me things like, "You must be appointed this year, or there will be consequences if you are not appointed". They say, "You do your best, and the rest is not important; you can prepare again the next year if you fail." I have set goals for myself. I have achieved these objectives in general. If I say I want to be appointed next year, I myself believe that I can study more and achieve it. But I don't expect I can make it this year, so I have no expectations this year. On the other hand, I haven't completely given it up; I am studying for the test whenever I find the opportunity.

\subsection{Catastrophizing}

It was observed that all of the prospective teachers who experienced anxiety about not being appointed were found to catastrophize the situation. Some of the participants' expressions are as follows.

N8: My family. They are unhappy. The important principle is that they should not get upset. I don't want to make them upset. I can't imagine I make them unhappy.

N8: After all, we are living. Money is necessary for everything. You have to work to earn money. We came here. We chose to be a teacher when we were eighteen or nineteen. It is necessary to be appointed to make it true. Okay, money is earned somehow, but if we want a more comfortable life, of course it is our priority to be appointed.

N8: Because I have studied hard; I have studied for four years. I have spent a lot of efforts, and therefore I would like to see I have realized my objectives. My years will be wasted if I can't.

N4: I will be depressed if I disappoint my family.

N2: I'm worried about what I will do next. In fact, I am planning to prepare for the test comfortably at home next year if I am not appointed. But my mother says, "No, you will work during the day and study for the test in the evening." This uncertainty scares me very much.

N1: Of course, I'll be depressed for a while.

Participants who did not have anxiety about not being appointed did not use cognitive distortions, but had alternative thoughts. The views of these participants are as follows.

N3: I do not think I will be unemployed if cannot get a good score from KPSS. I will find an alternative in some way.

N5: At worst, I will not work at all. I will relax. In fact, this is not that bad, either. 
N9: I go and live in the worst house. I can't imagine any worse. I will do my best to prevent it from happening because I had a bad experience at the beginning of this year. I recovered from it and came here.

\subsection{Physiological symptoms}

It was observed that five of the nine participants who had anxiety about not being appointed had physiological symptoms and that anxiety affected daily life. Participants' statements are as follows.

N8: There is stress in my daily life. I feel it physically. I have a lot of pimples. I have irregular meals. I have gained a lot of weight. This is how it usually shows up.

N4: My sleep pattern is ruined. So is eating and drinking. This has also affected my renal functions. I also have a problem with my stomach. My heart starts beating irregularly as I start thinking of it.

N1: My sleep, eating, and drinking patterns have become irregular. I am hungry, but I don't want to eat. I feel sick. Regarding how it affects my sleep patterns, either I sleep a lot or I can't sleep.

N9: I usually have a headache. I wake up with heart palpitations. I constantly feel hungry.

N11: My sleeping and eating patterns are disturbed. Sometimes I experience panic attacks.

\subsection{Doing preparations for getting appointed}

Three of the participants who experienced anxiety about preparation for appointment stated that they had no additional effort to be appointed. The statements of these participants are as follows.

N8: Yes, but I think I'm not doing enough preparation. This is the reason for my anxiety. If I felt like I am doing enough preparation, I would not worry that much, but I realize that I am not studying enough.

N2: No, I can't. Actually, I want to do it, but our school life is very busy. We have to deal with too many unnecessary things. That's why I can't. I haven't been able to open the cover of the book for two months. Right now, my only plan is to do something a little bit after graduation. The education system is also ridiculous to me. For example, I am studying English teaching, but they will ask me math questions in the test. I am not good at math. Since I cannot do these, my first test score will be low. This will affect my other test scores.

N7: I am not studying. Actually, I had been studying hard at the beginning of the semester. Later on, perhaps, studying with this ambition and effort over a long period of time could have brought me to a better position. In a short time and along with my school responsibilities, that ambition would bring me down, and my energy would be divided. I didn't do it.

Other participants who were concerned about not being appointed stated that they made an effort to be appointed, but they thought that they would not be appointed due to systemic reasons. The views of some of these participants are as follows.

N11: I do. I go to a course at weekends. But due to school and doing an internship, I cannot allocate enough time to study regularly. If I didn't have to attend school or I finished school, things might be different. 
N4: Because the necessary score for the appointment of English teachers used to be around sixty-five. Later, it increased to seventy-one. On the other hand, there are too many graduates. I am also studying. I know how to study. I also have a program for studying, but I am constantly interrupted, due to internship, the course, or school lessons... I attribute the anxiety of not being appointed to high scores.

N12: I am doing enough preparation, but there is something called "the unemployed with a university diploma". I do not think this anxiety can be prevented.

appointed, too.

It was observed that participants who did not experience anxiety made an effort to be

N6: Zero anxiety. These family ideas are also very important to me. This is my idea. That's, I have done what's necessary, and I have studied regularly. I have finished studying all the topics in three years. I did not have a problem as I studied it topic by topic. At the beginning of this semester, I revised all subjects for eight hours a day for two months. Now, I am doing field tests. I have managed the process in this way. There is nothing to do if I fail.

\subsection{Need for social support}

All of the participants stated that they used social support mechanisms for anxiety. The statements of some of the participants on this subject are as follows.

N4: Yes, I need support from time to time because I sometimes feel that I will give up everything. Then, I feel I need somebody to talk to.

N1: Usually my friends. They help me.

N7: My teachers support me. They support me and think I will have a good level of academic achievement. My teachers at the school where I'm doing an internship appreciate me a lot. My friends say I should do whatever I want and what I am happy with.

\section{Discussion, conclusions and recommendations}

One of the findings of this study was that most of the prospective teachers experienced anxiety about not being appointed and used similar concepts to explain not being appointed. Phrases obtained from the participants, such as frustration, wasted time, and shame caused by failure, are closely related to each other. Ending up with failure at the end of four years of education leads to disappointment, and due to this failure, the time spent at university is considered to be a waste of time despite the efforts of the students and their families, and as a result, the prospective teacher feels embarrassment. Finally, as the failure continues, this situation sooner or later leads the prospective teacher to the idea that he/she will be unsuccessful in the future, and takes him/her to a crossroads where he/she will abandon this goal and turn to new options.

Prospective teachers are generally stressed (Akpınar, 2013). One of the results obtained as a result of the data analysis was that most of the prospective teachers in the study group felt stressed and had anxiety about not being appointed. This finding is consistent with the findings of studies in the literature (Süner \& Eskici, 2020; Eskici, 2016; Arı \& Yılmaz, 2015; Kiraz, 2014; Akpınar, 2013). The prospective teachers in the study group tended to explain not being appointed mostly with changes that might occur in their psychological state. As can be seen, participants were predominantly in the middle-income group and their parents had a primary and secondary school level education. According to the findings of the research, prospective teachers stated that their families had high expectations from them and that their families imagined they 
could achieve anything because they had an undergraduate education. Parents with relatively low levels of education place great emphasis on the undergraduate education of their children, as they had been unable to continue their education for some reason. It can be said that this tendency, which becomes visible by parents' desire that their children can do what they could not do and which can be described as a kind of reflection, causes families to believe that their children are very successful and will continue to be. Noticing this belief, prospective teachers have high anxiety due to high expectations. As they know that thousands of students like them have received the same education, the place that they position themselves in the context does not match the place that their families locate them. This discrepancy may create an excessive sense of responsibility in the prospective teacher. This is a condition that can increase anxiety. Some prospective teachers in the research group pointed out that they felt very bad while explaining what not being appointed meant to them. However, they stated that this feeling was caused by their parents' overexaggerated assumptions about them. This may stem from the fact that Turkish culture has a relational self-construal, not an individualist one. In societies with relational self-construal, family relationships are an important element in the development and perception of the self. Süner and Eskici (2020) found that prospective teachers' perception of themselves was not negative towards not being appointed. At first glance, this situation seems inconsistent with the findings of our study. However, in our study, none of the prospective teachers indicated that they would hold themselves responsible for their failure if they could not get appointed. On the contrary, the vast majority of prospective teachers with high anxiety explained the factor that would make them feel bad, not with the appointment problem but with the attitudes and behaviors they expected to encounter in their families and environments. For this reason, the finding that at least some of the prospective teachers found flaws in the system and held the system responsible for their appointment problem is consistent with our study.

An effect similar to the anxiety of not being appointed comes from the environment. Arl and Yllmaz (2015) found that the vast majority of students who could not be appointed as a result of the common test developed the belief that they would encounter negative attitudes of the environment, they would be ridiculed, their value would decrease in the eyes of people, and that they would face pressure from their families regarding not being appointed. These findings are consistent with those of our study.

Almost all families believe that their children will be appointed and want to make them feel that they trust them to motivate them. However, the scene that the participants thought they would encounter in case of not being appointed varied. A small number of prospective teachers stated that their families did not put pressure on them. These participants also did not experience anxiety, either. It is possible to say that families with this perspective did not adopt an attitude that could cause negative anxiety at least. Also, students from such families stated that they did not see not being appointed as the end of everything. These prospective teachers stated that if they could not get appointed, they would prepare for the test again with the support of their families or teach in private institutions. This situation can be interpreted that the supportive, but not overloading, attitudes of the families cause the students to look more hopeful towards the future and that not being appointed does not mean that everything is over. It is possible to say that the families of prospective teachers play an important role in keeping their anxiety at a level that will take them to success. The prospective teachers, who stated that their anxiety was not at a disturbing level, were those who received support from their families and were not exposed to social pressure. Similarly, Arı and Yılmaz (2015) argued that increased family support decreased the perceived social pressure. Guay, Senécal, Gauthier and Fernet (2003) argue that positive family support reduces career uncertainty. In this case, the way the family reflects these attitudes and behaviors becomes as important as their attitudes and behaviors. However, the attitude of some families is among the reasons underlying the prospective teachers' anxiety about not being appointed. In the families of students who come from relatively small cities, especially where there are not many people with undergraduate education, this education may lead to the idea that the 
child will become a cultured, educated, and self-sufficient person. These families often unintentionally put too much responsibility on their children and generally ignore the possibility of not being appointed. Regardless of whether the families convey these thoughts to their children or not, it is understood from the statements of the participants that this situation causes a lot of stress and anxiety to them. Arl and Yllmaz (2015) revealed that approximately half of the prospective teachers believed that if they could not get appointed, they would face social pressure or family pressure. In this context, family pressure, which the prospective teacher believes exist or may exist in the near future, emerges as one of the important reasons for prospective teachers to develop negative anxiety. Perception towards family pressure may be due to the prospective teachers' misinterpretation of the situation. However, the perception of the existence or the possibility of family pressure in any way can lead prospective teachers to anxiety levels that can be associated with failure. When the statements of the participants are evaluated together, it can be said that the participants who perceived the expectations of their families as high felt more anxiety than the participants who perceived the expectations as low. At this point, it can be interpreted that the participants had social support expectations specifically from their families in terms of adapting to a new situation. Interpersonal relations psychotherapy is an effective method to regulate social relations in adapting to new situations (Hıll Sayar \& Omay, 2019). For this reason, it may be beneficial to use interpersonal psychotherapy when working with clients who have anxiety about not being appointed.

On the other hand, an important indicator of the unhappiness that the participants would experience if they were not appointed was due to the importance they attached to the test and their view of employment opportunities in case of failure. At this point, some participants thought that they could prepare for the test again or find a job in the labor market if they were not appointed, unlike the participants who catastrophized the likelihood of not being appointed. The limited number of participants who stated that they would evaluate the alternatives if they were not appointed may indicate a point where comfort and anxiety are balanced, which is expressed by the concept of constructive optimum tension (Scovel, 1978). Participants were aware of their alternatives and knew that they could survive in a way and stated that the common test was important. However, some prospective teachers did not feel anxiety and claimed that not being appointed was not important. Based on this, it can be seen that the cognitive interpretation of students is an important factor in their anxiety levels. It was observed that the participants generally used catastrophizing cognitive distortion. At the same time, it can be interpreted that the participants felt anxiety with realistic but dysfunctional thoughts. Therefore, it is predicted that cognitive-behavioral therapy strategies can be functional in the intervention.

According to the findings of the study, it was found that prospective teachers who had anxiety about not being appointed also showed the physiological symptoms of anxiety. Participants who experienced anxiety stated that they showed symptoms, such as nutrition, sleep disorders, and heart palpitations. This shows that the anxiety about not being appointed can be handled within the scope of anxiety disorders. Therefore, the procedures applied to intervene in anxiety can also be applied to the anxiety of not being appointed.

As far as the statements of the participants indicated, one of the most important predictors of anxiety was the state of whether they were prepared for the common test. The prospective teachers who thought that they were prepared enough for the test stated that they did not feel anxiety at a disturbing level, while the participants who were not prepared enough pointed out that not preparing for the test was one of the triggers of their anxiety. However, the participants did not always look for the reason for not being prepared enough in themselves. They stated that their busy schedule and having to deal with too many tasks at the same time caused them to stop preparing for the common test for some time. The fact that having to take a test, which very few candidates can win, without preparing enough was one of the factors that caused prospective teachers to worry about not being appointed. The anxiety of not being appointed 
increased in students who postponed the preparation for the common test due to other responsibilities. Some participants, on the other hand, stated that they were not worried at this point as they spread their studies over time before the intensive program in the last year of undergraduate education. The prospective teachers who were ready for the test stated that their readiness prevented them from experiencing anxiety. Considering this state of the prospective teachers, it can be concluded that not being prepared for the test increases anxiety.

When all study findings are evaluated together, it can be argued that the factor that causes prospective teachers to experience anxiety is their image of an uncertain future if they are not appointed. Mutlu et al. (2019) determined that the career planning of $80 \%$ of the prospective teachers primarily included being appointed to public schools. Another finding obtained in the same study was that only $19 \%$ of the prospective teachers did not experience career uncertainty. According to Mutlu et al. (2019), not knowing what to do in case of not being appointed is a great career uncertainty for prospective teachers. When this finding and the findings obtained in our study are evaluated together, it can be said that prospective teachers who do not know what to do if they are not appointed make appointment a very important goal, this leads to the anxiety of not being appointed and that they, therefore, believe that if they are not appointed, they will experience economic and psychological problems. Ince-Aka and Yllmaz (2018) listed the reasons underlying the prospective teachers' anxiety of not being appointed as the thought of being unemployed, the status of not being prepared enough for the test, the high number of candidates, and high scores necessary for appointment. The thought of being unemployed and not being ready for the test, which are among the findings of Ince-Aka and Yilmaz, are remarkable facts that play a role in experiencing anxiety. Facing a highly difficult test to overcome is likely to lead prospective teachers to career uncertainty and the thought of being unemployed as a natural consequence. Not being ready for the test affects anxiety, and this can be explained by the concept of low self-efficacy expectations, the theoretical background of which was established by Bandura. According to this concept, low self-efficacy expectation increases anxiety. According to Bandura, the developer of the self-efficacy theory, as self-efficacy expectations increase, anxiety decreases, and as they decrease, anxiety increases (Taylor \& Betz, 1983). Prospective teachers who have low self-efficacy expectations for both being successful in the common test and finding a good job experience career uncertainty. A natural consequence of career uncertainty and low self-efficacy expectations is anxiety. It is thought that this approach makes the anxiety of not being appointed more intelligible.

Career uncertainty is closely related to future anxiety, and it is supported by academic studies that a career choice with only one option at its focus increases anxiety (Mutlu et al., 2019). According to Cüceloğlu (2006), future uncertainties lead to anxiety (cited in Eskici, 2016). In this context, the uncertainty about whether the teachers will be successful in the common test and the uncertainty in career choices to be made due to the failure to be appointed to public schools are among the reasons for the intense anxiety of prospective teachers. On the basis of this uncertainty lies the preferred model of teacher recruitment in Turkey and inadequate social and economic conditions of the private institutions employing teachers. Akoğlan, Kozak and Dalkıranoğlu (2013) found that a significant proportion of university students tended to turn to graduate education before entering working life. Mutlu et al. (2019) revealed that students primarily aimed to be appointed to public schools, and if they failed to do so, they wanted to do graduate education. Similarly, in our study, it was understood that the primary goal of the students was to be appointed to public schools and that most of these students considered the failure in this goal as an important loss. 


\section{Acknowledgements}

This research did not receive any specific grant from funding agencies in the public commercial, or not-for-profit sectors.

The authors declare no competing interests.

\section{References}

Akoğlan Kozak, M., \& Dalkıranoğlu, T. (2013). Career perceptions of new graduates: Anadolu University example. Anadolu University Journal of Social Sciences, 13(1), 41-52.

Akpınar, B. (2013). Analysis of candidate teachers' stress level in terms of different variables. Dicle University Journal of Ziya Gökalp Education Faculty, 21, 229-241.

Anthony, M., \& Swinson, R. (2000). Phobic disorders and panic in adults. Washington, DC: American Psychological Association.

Arı, E. \& Yılmaz, V. (2015). Hopelessness levels of teachers who follow kpss preperation courses. Gaziantep University Journal of Social Sciences, 14(4), 905-931.

Beck, A. T., Rush, A. J., Shaw, B. F., \& Emery, G. (1979). Cognitive therapy of depression. New York: The Guilford Press.

Burns, D. D. (2014). Feeling good: New mood therapy. İstanbul: Psikonet Publications.

Creswell, J. (2016). Research design: Qualitative, quantitative, mixed methods approaches. University of Nebraska-Lincoln.

Cüceloğlu, D. (2016). Human and its behavior: Basic concepts of psychology. Istanbul: Remzi Publishing

Çokluk, Ö. (2000). Burnout in organizations: Contemporary approaches in management. (Eds.: C. Elma \& K. Demir). Ankara: Anı Publishing

Eskici, M. (2016). Determine the anxiety of pre-service teachers' not to be appointed to teachership in the light of some variables. Turkish Studies, 11(19), 361-378.

Fair, S. E. (1986). Cognitive content and distortion associated with mood-induced depressive and anxious states. Arizona: Arizona State University.

Guay, F., Senécal, C., Gauthier, L., \& Fernet, C. (2003). Predicting career indecision: A self-determination theory perspective. Journal of Counseling Psychology, 5o(2), 165-191.

Hızlı Sayar G., \& Omay, O. (2019). What is interpersonal psychotherapy? In N. Aydın \& O. Omay (Eds), Interpersonal relations psychotherapy. Ankara: Turkey Clinics.

İnce-Aka, E., \& Yılmaz, M. (2018). A study on the examination of the unemployment anxiety of prospective science teachers. Journal of Research in Education and Society, 5(1), 105-123.

Johnson, R. B., \& Christensen (2014). Educational research: Quantitative, qualitative and mixed approaches (5th edit.). Los Angeles: Sage.

Johnson, S. B., \& Melamed, B. G. (1979). The assessment and treatment of children's fear. In B. B. Lahey \& A. E. Kazdin (Eds.), Advances in clinical child psychology (pp. 107-139). New York: Plenum Press.

Kiraz, Z. (2014). Unemployment of teachers in Turkey and analysis of unassigned teachers' act (Unpublished doctoral dissertation). Ankara University Institute of Educational Sciences, Ankara. 
Manav, F. (2010). The concept of anxiety in Soren Kierkegaard (Unpublished Master's Thesis). Gazi University Institute of Educational Sciences, Ankara

Mckenzie, K. (2006). Anxiety and panic attack (Translation: Ü. Şensoy). Istanbul: Morpa Cultural Publications.

MEB (2017). Official letter dated 06.o6.2017 sent from the Ministry of National Education to the Higher Education Council. Retrieved from http://oygm.meb.gov.tr/meb_iys_dosyalar/2017_12/06164534_YYretmenlik_uygulamasY.p df.

Merriam, S. B. (2013). Qualitative research: A guide to design and implementation ( $3^{\text {rd }}$ Edition, Translation: S. Turan). Ankara: Nobel Publishing.

Ministry of National Education (2017). Teacher strategy document 2017-2023. Ankara.

Mutlu, T., Korkut-Owen, F., Özdemir, S., \& Ulaş-Kılıç, Ö. (2019). Career plans, career indecision and strategies for coping with career indecision among teacher candidates. Journal of Career Counseling, 2(1), 1-31.

Öner, N., \& Le Compte, A. (1998). Discontinuous state / Trait anxiety inventory handbook. Istanbul: Boğaziçi University Publications.

Özden, M., \& Saban, A. (2017). Paradigm and theoretical foundations in qualitative research. A. Saban \& A. Ersoy (Eds.). In qualitative research designs in education (pp. 1-29). Ankara: Anı Publishing.

Scovel, T. (1978). The effect on foreign language learning: A review of the anxiety resarch. Language Learning, 28(1), 129-142.

Semerci, B. (2007). Exam stress and ways to cope. Istanbul: Central Publishing.

Smith, C., \& Lazarus, R. (1990). Emotion and adaptation. L.A.: Pervin

Spielberger, C. D. (1972). Current trends in theory and research on anxiety. In C. D. Spielberger (Ed.), Anxiety. New York: Academic Press.

Süner, Ş., \& Eskici, M. (2020). The anxiety of pre-service teachers' not to be appointed to teachership in terms of level of hopelessness, gender, school type. Celal Bayar University Journal of Social Sciences, 18, 357-372.

Tarhan, N. (2012). My young friend. İstanbul: Timaş Publishing.

Taylor, K. M., \& Betz, N. E. (1983). Applications of self-efficacy theory to the understanding and treatment of career indecision. Journal of Vocational Behavior, 22(1), 63-81.

Yeni Çağ (2018, 18 Nisan). The news titled "He ended his life because 42 teachers could not be appointed in 2 years.". Retrieved from https://www.yenicaggazetesi.com.tr/2-yilda-42-ogretmenatanamadigi-icin-hayatina-son-verdi-19006oh.htm.

Yerkes, R. M., \& Dodson, J. D. (1908). The relation of strength of stimulus to rapidity of habit-formation. $J$. Comp. Neurol. Psychol., 18, 459-482.

Yıldırım, A., \& Şimşek, H. (2000). Qualitative research methods in the social sciences. Ankara: Seçkin Publishing.

Zaleski, Z. (1996). Future anxiety: Concept, measurement, and preliminary research. Lublin. Poland: Psychology Department, Catholic University of Lublin, Al. Raclawickie. 